\title{
The Role of CDS Market in the Price Discovery Process of the "PIIGS" Countries Sovereign Credit Risk During the Recent Decade of Monetary Easing
}

\author{
Michele Anelli ${ }^{1}$ and Michele Patanè ${ }^{2}$
}

\begin{abstract}
The aim of this paper is to analyze the long-lasting dynamic relationship between the credit default swap (CDS) premia and the government bond spreads (GBS), with regard to the sovereign credit risk. The practical focus is to evaluate whether the CDS market effectively is the leading or the lagging market in the credit risk price discovery process during the last decade of monetary easing. The analysis extends to all "sensitive" countries in the Eurozone, the so-called "PIIGS" countries ${ }^{3}$ (excluded Greece) for the interval 2007-2017.
\end{abstract}

JEL classification numbers: G01, G12, G14, G20.

Keywords: CDS spread, Government bond spread, Sovereign credit risk, Cointegration, Vector error correction model, Granger-causality.

${ }^{1} \mathrm{PhD}$, Department of Business and Law, School of Economics and Management, University of Siena, Siena, Italy.

2 Associate Professor, Department of Business and Law, School of Economics and Management, University of Siena, Siena, Italy.

3 "PIIGS" is the indelicate acronym used by the press to indicate the Eurozone peripheral countries: Portugal, Ireland, Italy, Greece and Spain.

Article Info: Received: November 15, 2021. Revised: December 5, 2021.

Published online: December 9, 2021. 


\section{Introduction}

Under normal market conditions, both in the long and short term, the quotations of the government bonds and CDS premia (for the same period and reference entity) are sufficiently correlated and leave no margin for arbitrage opportunities. The same does not happen, especially as regards the short term, in conditions of financial instability similar to those that have characterized the markets in these recent years. This latter observation, in relation to the Eurozone sovereign markets, offers the opportunity to check whether in the adjustment process among the different considered spreads, a leading market and a possible lagging one, emerges. The recent crisis, indeed, has contributed to deteriorate the sovereign States fiscal conditions, with an evident higher pressure on the weakest economies, destabilizing the normal financial markets functioning. Therefore, we would like to analyze the connection among the time series of government bond spreads, calculated as differential between the respective 10-years benchmark bond yields and the Bund yield, and the relative CDS spreads (or premia). The aim is to evaluate their different ability of immediately incorporating the information on credit risk during a period of deep systemic crisis, such as that of the recent economic crisis. Why have we decide to extend the analysis for the PIIGS countries - except Greece? These countries represent the most vulnerable economies inside the Euro Area and, in turn, the most preferred countries for speculative attention by international financial operators during periods of greater socio-political instability, characterized by very high debt-to-GDP ratios, high deficits and a high ratio of net debt interest payments to GDP. As is well known, Portugal, Italy, Ireland, Greece and Spain were the hardest hit countries by financial crisis and still to this day market operators follow them with particular focus. Greece is not in this empirical evidence due to the anomalous situation of this country, subjected to the supervision of Troika (ECB, IMF and EU Commission).

The CDS, by definition, is the basic Over The Counter (OTC) financial instrument for measuring the credit risk of the reference entity, generally used more frequently to implement financial hedging rather than for speculative strategies, that can be interpreted as a credit spread on a bond issued by the reference entity. It is proper to remark that the credit risk is not the only determinant (Elton et al., 2001; Fontana et al., 2016). CDS contracts, indeed, transfer the credit risk associated with corporate or sovereign bonds to a third part, exposing the protection buyer to the counterparty risk4. Moreover, the Cheapest to Deliver (CTD) option embodied in many physically settled CDS contracts might affect the basis, although the impact of this factor might be small for sovereign CDS, because they are more frequently settled in cash (Palladini et al., 2011).

If the credit risk were the main priced factor, as already mentioned, what we should find is a close co-movement of these series. Therefore, the fundamental and simplifying assumption is that the main priced factor is the credit risk.

\footnotetext{
${ }^{4}$ It is the risk that the protection seller will not be able to provide a compensation payment in case a credit event (or trigger event) occurs.
} 
The bond spread (BS) is generally the differential with respect to the associated swap rate. The government bond spread (GBS), on the contrary, is defined as difference between the 10-years yield of a government bond and the 10-years yield of another one with AAA rating (like Germany, that is the main core country in the Euro Area). Even this latter embodies different typology of risks and not only the pure credit risk (i.e., liquidity risk, expectation on future inflation, growth capacity, etc.).

\section{Literature Review}

There is nowadays an extensive literature about sovereign credit risk and on the fundamental role of the CDS market in the price discovery process of it. Particularly after the recent global financial crisis and more intensively after the Eurozone sovereign debt crisis, several authors have investigated on the relationship between CDS premia and government bond spreads trying to evaluate some changes in the pricing process of the credit risk due to dynamic changes in the markets structure. Duffie (1999) was the first author to claim the absence of arbitrage opportunities on the so-called "CDS-bond basis", that is the differential between the CDS premium and the bond spread (the differential between a risky bond asset and a risk-free bond asset yield) with the same expiry and an equal notional value. Amadei et al. (2011), however, point out that CDS-bond basis arbitrage opportunities emerge in more turbulent market backdrops.

After the sovereign debt crisis in Eurozone, indeed, different studies observed a persistent non-zero CDS-bond basis in Euro Area sovereign debt markets. Gyntelberg et al. (2016) try to explain the persistent and increasing non-zero CDSbond basis in Euro Area sovereign debt markets during the last sovereign crisis. They suggest that the significant increase in the basis was due to sharply higher transaction costs facing arbitrageurs in the market, negatively affecting their riskreward profile.

The increasing attention on the intermarket connections between the CDS and bond market attracted many researchers to investigate further on the different ability of these markets to promptly incorporate the credit risk information in order to test the efficiency in different market frameworks and evaluate possible strategies based on credit risk.

Palladini and Portes (2011) test the price discovery relationship between sovereign CDS premia and bond yield spreads on the same reference entity. Focusing on the Euro Area countries over the period 2004-2011, they prove that the CDS market leads the bond market in the price discovery process of credit risk.

Andenmatten et al. (2011) examine the empirical relationship between CDS premia and government bond spreads for Portugal, Italy, Ireland, Greece, and Spain (the "PIIGS" countries) for the period from January 2007 to April 2010. They conclude that, in most cases (five out of seven), only CDS premia contribute to the price discovery process during the analyzed period.

Ito (2016) shows that, for the period from January 2009 to September 2011, 
sovereign CDS (five-year maturity) and government bond markets are integrated only in the Netherlands and not in Austria, Belgium, Finland, France, Germany, Greece, Italy, Ireland, Portugal, or Spain. Even though the CDS and government bond markets are distinct, mutual influences between them have been found in Greece, Italy, Ireland and Portugal with a one-way influence from the government bond market to the CDS market in Spain.

With exclusive focus on the Italian case, Anelli et al. (2021) conclude that, in normal market conditions, the CDS is the best instrument in the price discovery process of the credit risk. In particular, during the financial crisis (2007-10), when markets lacked liquidity, the CDS market leads the bond market to incorporate more rapidly the sovereign credit risk information. In the following period, when markets started to be affected by the expansive ECB monetary policy, albeit maintaining part of their normal structure, this relationship reverses. In fact, during the sovereign debt crisis (2010-12), the bond market leads the CDS market to incorporate more rapidly the sovereign credit risk information.

The analysis of these dynamic intermarket connections allow market operators to capture signals of inversion or trend reinforcement and then to implement worthwhile strategies. Moreover, for policy-makers, an in-depth knowledge of these dynamics creates the conditions for adopting timely and well-balanced monetary policies. This paper proposes to provide an additional contribution to the existing literature focusing on the potential impact on the price discovery process of the sovereign credit risk and on eventual differences among Eurozone peripheral countries during this last decade of monetary policy easing. Specifically, by means of a very recent time series analysis starting from the financial crisis up to the initial fourth quarter of the 2017, we would like to highlight how traditional markets can change in particular economic contexts and be deeply affected by monetary policies. A minor aim (but not less important), linked to the previous one, is to emphasize the different impact of a stressed market condition on different socio-economic entities. The "flight-to-liquidity" investors' behavior, in fact, not necessarily can be a consequence of a structural change, but a further boost in response to the volatile pre-existent economic backdrop of a peculiar country. Hypothesis: based on the above discussion, we develop the following hypotheses.

H1: The fundamental and simplifying assumption is that the main priced factor is the credit risk.

\section{Model and Data description}

In order to realize the empirical analysis we use daily price quotes for the sovereign PIIGS - except Greece 10y CDS contracts and the 10y government bond spreads for the time interval 2007-2017 (2521 observations for Portugal; 1955 observations for Ireland; 2522 observations for Italy; 2522 observations for Spain). Daily basis 
data provided by Bloomberg. The descriptive statistics of the dataset are shown in Table 1. The overtime movements of the 10y CDS premia and government bond yield spreads for Portugal, Ireland, Italy and Spain are shown respectively in Figures 1, 2, 3 and 4.

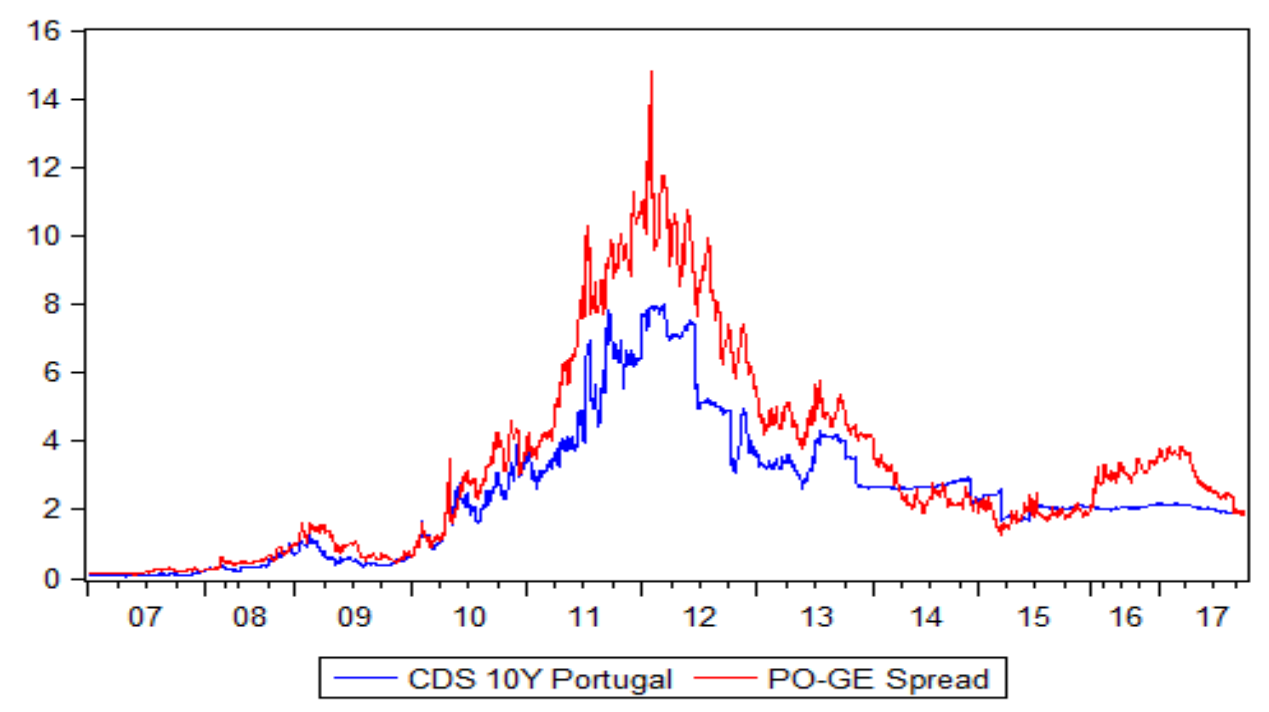

Figure 1: CDS spreads and government bond spreads series from January 2007 to October 2017 - Portugal (authors' own calculations in Eviews 10)

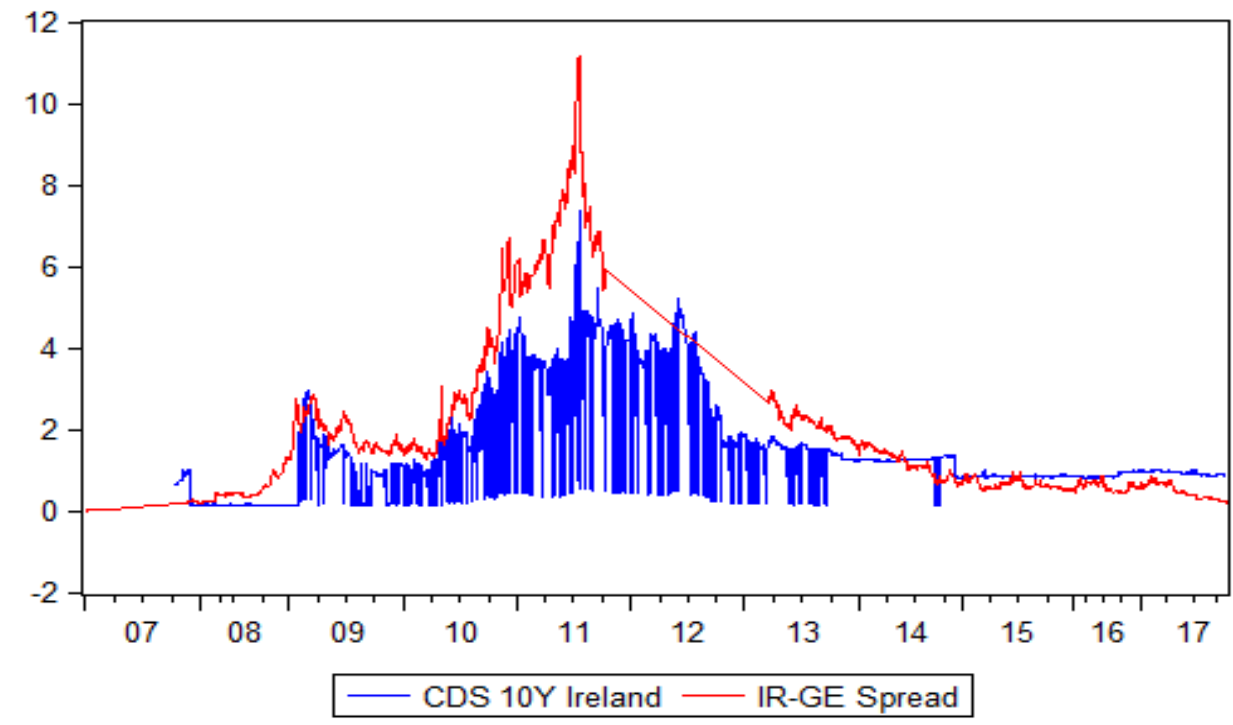

Figure 2: CDS spreads and government bond spreads series from January 2007 to October 2017 - Ireland (authors' own calculations in Eviews 10) 


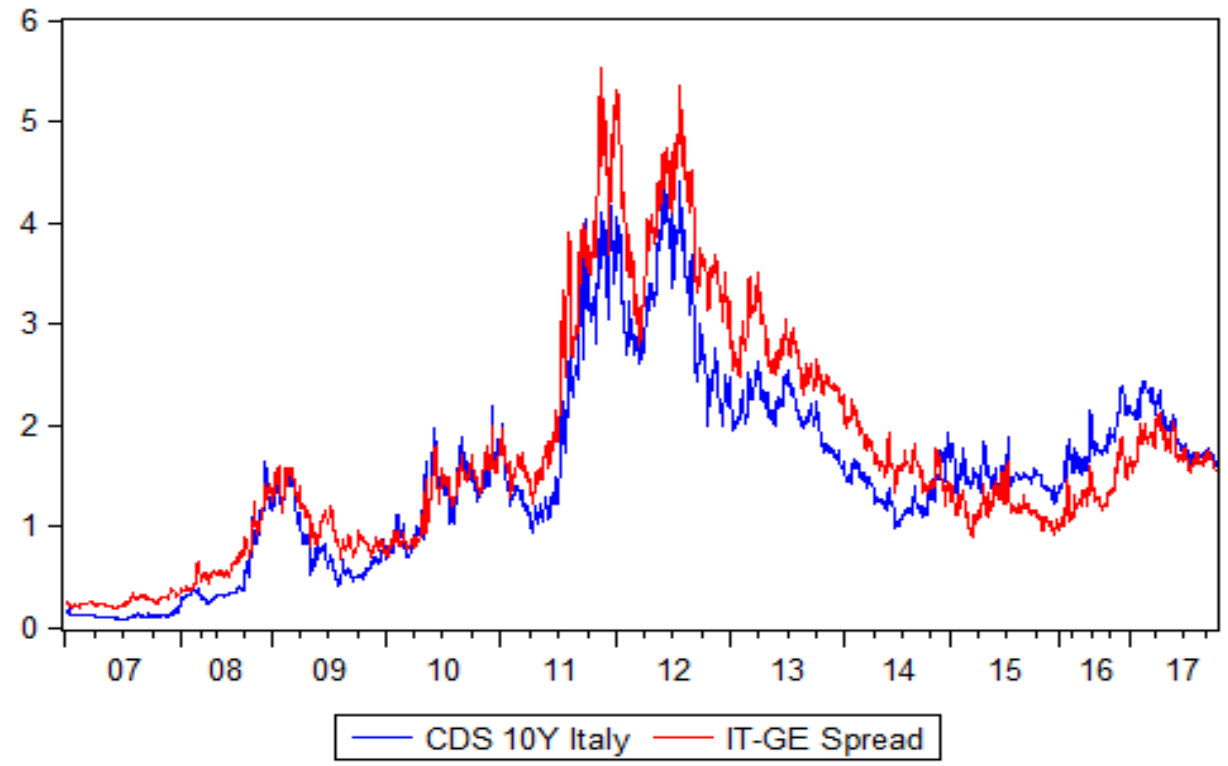

Figure 3: CDS spreads and government bond spreads series from January 2007 to October 2017 - Italy (authors' own calculations in Eviews 10)

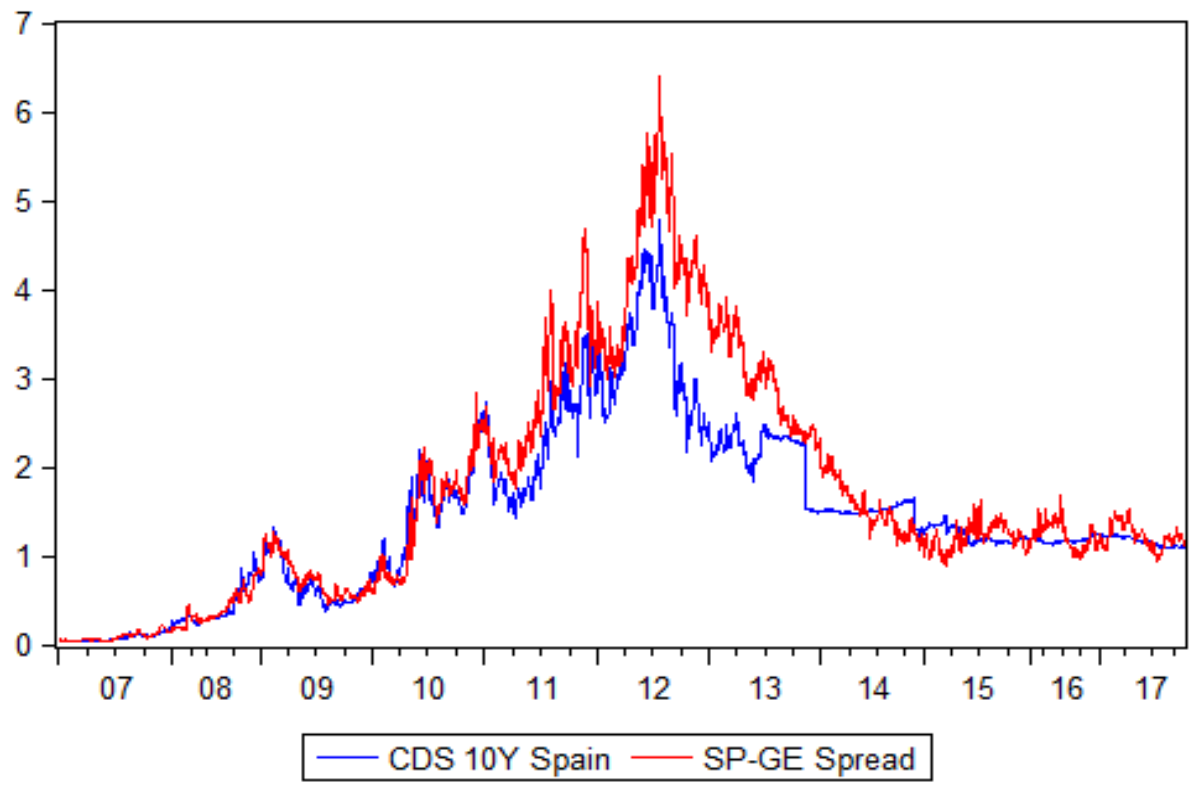

Figure 4: CDS spreads and government bond spreads series from January 2007 to October 2017 - Spain (authors' own calculations in Eviews 10) 
Table 1: Descriptive statistics of data. Sample period is from January 2007 to October 2017 (Bloomberg)

\begin{tabular}{|l|c|c|c|c|c|}
\hline \multicolumn{1}{|c|}{ Variable } & Mean & SD & Min & Max & Median \\
\hline \multicolumn{1}{|c|}{ 10y CDS premia } & \multicolumn{5}{c|}{ (basis points - 0.01\% ) } \\
\hline Portugal & 244.13 & 192.28 & 5.59 & 798.63 & 212.72 \\
\hline Ireland & 127.01 & 114.17 & 11.12 & 738.32 & 94.76 \\
\hline Italy & 151.66 & 93.79 & 8.21 & 441.51 & 147.47 \\
\hline Spain & 143.75 & 95.16 & 4.15 & 477.39 & 123.78 \\
\hline 10y government bond yield spreads & \multicolumn{5}{|c|}{$(\%)$} \\
\hline Portugal & 3.27 & 2.88 & 0.11 & 14.81 & 2.48 \\
\hline Ireland & 1.90 & 2.01 & 0.16 & 11.14 & 1.34 \\
\hline Italy & 1.71 & 1.14 & 0.19 & 5.53 & 1.47 \\
\hline Spain & 1.69 & 1.30 & 0.03 & 6.39 & 1.30 \\
\hline
\end{tabular}

The econometric model implemented is based on the methodology suggested by Gonzalo and Granger (1995). De Jong (2002) shows that, although GonzaloGranger and Hasbrouck approaches have their merits, the former is useful if one wants to construct the innovations in the efficient price from the full innovation vector (the major difference between the two approaches is the role of the variance of innovations). The analysis, therefore, develops in two stages.

In the first stage, we verify whether the short-term deviations of these two series converge towards the long-term equilibrium through a «cointegration analysis». The existence of a linear combination between these two series, indeed, supports the presence of a long-term equilibrium adjustment process, even if the series deviate one from the other in the short-term. In this case, series are cointegrated. In the second stage, by using the first stage results ${ }^{5}$, we will try to verify which market is able to embody more rapidly the risk information. In other terms, this allows us to evaluate the potential existence of a leader and follower market, as well as halfway situations. To do so, we set a bivariate Vector Error Correction Model (VECM), as suggested by Engle and Granger (1987).

${ }^{5}$ If the two series are not cointegrated then the VECM cannot be implemented because it is no more valid. In this case, we analyze the Granger-causality and the Impulse Responses by estimating an unrestricted VAR. 
The formal specification of the model is defined by the following equations:

$$
\begin{aligned}
& \Delta C D S_{t}=\beta_{10}+\sum_{t=1}^{l} \beta_{1 t} \Delta C D S_{t-1}+\sum_{t=1}^{l} \alpha_{1 t} \Delta G B S_{t-1}+\lambda_{1} E C T_{t-1}+\varepsilon_{1 t} \\
& \Delta G B S_{t}=\beta_{20}+\sum_{t=1}^{l} \beta_{2 t} \Delta C D S_{t-1}+\sum_{t=1}^{l} \alpha_{2 t} \Delta G B S_{t-1}+\lambda_{2} E C T_{t-1}+\varepsilon_{2 t}
\end{aligned}
$$
where:

- $\triangle C D S_{t}$ and $\triangle G B S_{t}$ are, respectively, the first differences for the sovereign $10 \mathrm{y}$ CDS spreads and the $10 \mathrm{y}$ government bond yield spreads series;

- $\quad \beta_{10}$ and $\beta_{20}$ are, respectively, the constant terms of the equation (1) and (2);

- $\triangle C D S_{t-1}$ and $\triangle G B S_{t-1}$ are, respectively, the delayed first differences for the sovereign $10 \mathrm{y}$ CDS spreads and the $10 \mathrm{y}$ government bond yield spreads series;

- $l$ is the number of lags;

- $E C T_{t-1}$ is the Error Correction Term (ECT). It is defined as $E C T_{t-1}=$ $C D S_{t-1}-\alpha-\gamma G B S_{t-1}$. In simple terms, it measures the deviations between the CDS and GBS at time (t-1) with respect to the theoretical long period equilibrium. $\gamma$ is the cointegrating coefficient and $\alpha$ is the intercept of the cointegrating term;

- $\lambda_{1}$ and $\lambda_{2}$ are the adjustment coefficients. They describe the speed of adjustment back to the long period equilibrium, that is they measure the proportion of correction of the series deviations from the long-run relationship;

- $\varepsilon_{1 t}$ and $\varepsilon_{2 t}$ are, respectively, the error terms of the equation (1) and (2).

It is intuitive that, for the aim of the analysis, the evaluation of the $\operatorname{sign}^{6}$ and the statistically significance of the adjustment coefficients $\left(\lambda_{1}\right.$ and $\left.\lambda_{2}\right)$ allows us to know which market contributes to the adjustment process toward the long period equilibrium and which market is able to embody more rapidly the credit risk information than the other one. Hence, we should distinguish four cases:

- if $\lambda_{1}$ is statistically significant and negative then it implicitly means that the bond market embodies more rapidly the credit risk information than the sovereign CDS market. This means that the sovereign CDS market is trying to restore the long-run equilibrium;

- if $\lambda_{2}$ is statistically significant and positive then it implicitly means that the sovereign CDS market embodies more rapidly the credit risk information than the bond market. This means that the bond market is trying to restore the long-run equilibrium;

- if $\lambda_{1}$ is statistically significant and negative and $\lambda_{2}$ is statistically significant and positive then both markets contribute to the adjustment process towards the long-run equilibrium. In this case, by following Gonzalo-Granger (1995), in order to evaluate the effective contribution of each market in the

\footnotetext{
${ }^{6}$ We should expect the negative sign for $\lambda_{1}$ and the positive sign for $\lambda_{2}$ in order to favor the process of adjustment.
} 
adjustment process, we follow the concept of Market Share (MS) ${ }^{7}$. According to how the MS formula has been defined, we distinguish between three sub cases:

a) if $\mathrm{MS} \approx 1$ then the sovereign CDS market is the leading market and the bond market is the lagging market;

b) if $\mathrm{MS} \approx 0$ then the bond market is the leading market and the sovereign CDS market is the lagging market;

c) if MS $\approx 0.5$ then both market contribute in the same way;

- if only one of the adjustment coefficients is statistically significant and it present the correct sign then only that market contributes to the price discovery of the credit risk and to the adjustment process towards the equilibrium.

Given that the implementation of the just described model (bivariate VECM) requires that the two series are cointegrated, if this is not the case, then we set an unrestricted VAR to estimate the possible existence of a Granger-causality (unidirectional or bilateral) and, eventually, the Impulse Responses.

\section{Results}

In this section, results are presented separately for each peripheral country. All preliminary and complementary tests on time series are reported in the Appendix. Further statistical tests validating the acceptance of OLS assumptions are not reported here. With regard to these latter tests, they confirm the presence of no serial correlation, heteroskedasticity and non-normal distributed residuals. To limit the problem of the heteroskedasticity, we calculated robust estimates by using the Huber-White procedure. The normality assumption allows exact inference about the estimates and standard errors of the estimated coefficients. However, even when the normality assumption is not valid (but all the other assumptions are), the estimates are still consistent and the Central Limit Theorem allows to make inferences that are valid in an asymptotic sense (Wooldridge, 2003).

In the set up of VAR models, in order to choose the optimal lag length, I followed the Hannan-Quinn criterion as suggested by Liew $(2004)^{8}$. Moreover, the VAR models are stable (not poor) ${ }^{9}$.

\subsection{Portugal}

According to the first stage of the analysis, we evaluate the existence of cointegration between the two series through the Augmented Dickey-Fuller Test. The latter is detailed below in the Table 2 .

\footnotetext{
7 The formula suggested by Gonzalo and Granger (1995) is the following: $M S=\frac{\lambda_{2}}{\lambda_{2}-\lambda_{1}}$

${ }^{8}$ According to the author, the Hannan-Quinn criterion is the most efficient when observations are above 120 .

${ }^{9}$ See the AR root graphs in the Appendix.
} 
Table 2: Augmented Dickey-Fuller Test - period 2007-17 (authors' own calculations in Eviews 10)

\begin{tabular}{|l|c|c|}
\hline \multicolumn{3}{|c|}{ Augmented Dickey-Fuller Test } \\
\hline Rountry & t-Statistic & Prob. $^{*}$ \\
\hline Portugal & -6.190656 & 0.0000 \\
\hline
\end{tabular}

As suggested by the test, the two series are cointegrated. Therefore, it is possible to realize the second stage of the analysis and estimate the VECM in order to assess which market contributes to the adjustment process toward the long period equilibrium and which one is "the more efficient" in incorporating more rapidly the sovereign credit risk information. The VECM estimation outputs are reported in the following Table 3 (a) and Table 3 (b).

Table 3 (a): Dependent variable $\triangle C D S$ - period 2007-17 (authors' own calculations in Eviews 10)

\begin{tabular}{|c|c|c|c|c|}
\hline & Coefficient & Std. Error & t-Statistic & Prob. \\
\hline$\beta_{10}$ & 0.000764 & 0.002232 & 0.342419 & 0.7321 \\
\hline$\beta_{11}$ & 0.052349 & 0.033257 & 1.574091 & 0.1156 \\
\hline$\beta_{12}$ & -0.005193 & 0.031991 & -0.162313 & 0.8711 \\
\hline$\beta_{13}$ & $-0.080165^{* *}$ & 0.041095 & -1.950733 & 0.0512 \\
\hline$\beta_{14}$ & -0.005979 & 0.032382 & -0.184624 & 0.8535 \\
\hline$\beta_{15}$ & -0.001847 & 0.045229 & -0.040835 & 0.9674 \\
\hline$\alpha_{11}$ & $0.104716^{* * *}$ & 0.027412 & 3.820023 & 0.0001 \\
\hline$\alpha_{12}$ & -0.013685 & 0.025286 & -0.541202 & 0.5884 \\
\hline$\alpha_{13}$ & 0.029657 & 0.028871 & 1.027222 & 0.3044 \\
\hline$\alpha_{14}$ & -0.028261 & 0.020001 & -1.412948 & 0.1578 \\
\hline$\alpha_{15}$ & 0.005606 & 0.026044 & 0.215266 & 0.8296 \\
\hline$\lambda_{1}$ & $-0.021620^{* * *}$ & 0.006571 & -3.290275 & 0.0010 \\
\hline
\end{tabular}

Note: $* * *$ signals parameter significance at $1 \%$. 
Table 3 (b): Dependent variable $\triangle G B S$ - period 2007-17 (authors' own calculations in Eviews 10)

\begin{tabular}{|l|c|c|c|l|}
\hline & Coefficient & Std. Error & t-Statistic & Prob. \\
\hline$\beta_{20}$ & 0.000823 & 0.002874 & 0.286169 & 0.7748 \\
\hline$\beta_{21}$ & $0.091262^{*}$ & 0.048073 & 1.898394 & 0.0578 \\
\hline$\beta_{22}$ & 0.006391 & 0.050463 & 0.126654 & 0.8992 \\
\hline$\beta_{23}$ & -0.012191 & 0.063786 & -0.191126 & 0.8484 \\
\hline$\beta_{24}$ & -0.012764 & 0.046856 & -0.272417 & 0.7853 \\
\hline$\beta_{25}$ & $-0.084659^{*}$ & 0.051226 & -1.652646 & 0.0985 \\
\hline$\alpha_{21}$ & $0.135421^{* *}$ & 0.065250 & 2.075409 & 0.0381 \\
\hline$\alpha_{22}$ & -0.005310 & 0.051762 & -0.102591 & 0.9183 \\
\hline$\alpha_{23}$ & 0.038917 & 0.043861 & 0.887294 & 0.3750 \\
\hline$\alpha_{24}$ & $-0.150812^{* * *}$ & 0.056421 & -2.672956 & 0.0076 \\
\hline$\alpha_{25}$ & 0.055169 & 0.035967 & 1.533870 & 0.1252 \\
\hline$\lambda_{2}$ & 0.010336 & 0.007791 & 1.326602 & 0.1848 \\
\hline
\end{tabular}

Note: $* * *$ signals parameter significance at $1 \%$.

As we can see from Table 3 (a) and Table 3 (b), only $\lambda_{1}$ is statistically significant and negative while $\lambda_{2}$ is positive but not statistically significant. This result implicitly means that the bond market (lead) embodied more rapidly the credit risk information than the $C D S$ market (lag) during the selected time interval and that the latter market moved in the direction to restore the long-run equilibrium relationship.

\subsection{Ireland}

Also for Ireland, we evaluate the existence of cointegration between the two series through the Augmented Dickey-Fuller Test. The latter is detailed below in the Table 4. 
Table 4: Augmented Dickey-Fuller Test - period 2007-17 (authors' own calculations in Eviews 10)

\begin{tabular}{|l|l|l|}
\hline \multicolumn{3}{|c|}{ Rugmented Dickey-Fuller Test } \\
\hline Country & t-Statistic & Prob. ${ }^{*}$ \\
\hline Ireland & -5.027472 & 0.0000 \\
\hline
\end{tabular}

The test suggests that the two series are cointegrated. The VECM estimation outputs are reported in the following Table 5 (a) and Table 5 (b).

Table 5 (a): Dependent variable $\triangle C D S$ - period 2007-17 (authors' own calculations in Eviews 10)

\begin{tabular}{|c|c|c|c|c|}
\hline & Coefficient & Std. Error & t-Statistic & Prob. \\
\hline$\beta_{10}$ & 0.001986 & 0.013647 & 0.145560 & 0.8843 \\
\hline$\beta_{11}$ & $-0.530842^{* * *}$ & 0.064687 & -8.206368 & 0.0000 \\
\hline$\beta_{12}$ & $-0.344535^{* * *}$ & 0.075563 & -4.559596 & 0.0000 \\
\hline$\beta_{13}$ & $-0.264598^{* * *}$ & 0.074200 & -3.566033 & 0.0004 \\
\hline$\beta_{14}$ & $-0.204584^{* * *}$ & 0.073859 & -2.769921 & 0.0057 \\
\hline$\beta_{15}$ & $-0.139232^{*}$ & 0.072580 & -1.918333 & 0.0552 \\
\hline$\beta_{16}$ & -0.072505 & 0.065785 & -1.102144 & 0.2705 \\
\hline$\beta_{17}$ & -0.016081 & 0.056382 & -0.285211 & 0.7755 \\
\hline$\beta_{18}$ & 0.038456 & 0.040298 & 0.954297 & 0.3401 \\
\hline$\alpha_{11}$ & 0.429258 & 0.281974 & 1.522329 & 0.1281 \\
\hline$\alpha_{12}$ & 0.115460 & 0.350327 & 0.329578 & 0.7418 \\
\hline$\alpha_{13}$ & 0.121669 & 0.302824 & 0.401781 & 0.6879 \\
\hline$\alpha_{14}$ & 0.063924 & 0.297268 & 0.215038 & 0.8298 \\
\hline$\alpha_{15}$ & -0.332151 & 0.242476 & -1.369831 & 0.1709 \\
\hline$\alpha_{16}$ & -0.418851 & 0.376825 & -1.111528 & 0.2665 \\
\hline$\alpha_{17}$ & 0.350017 & 0.434632 & 0.805318 & 0.4207 \\
\hline$\alpha_{18}$ & $-2.16 \mathrm{E}-05$ & 0.372100 & $-5.81 \mathrm{E}-05$ & 1.0000 \\
\hline$\lambda_{1}$ & $-0.317278^{* * *}$ & 0.049432 & -6.418433 & 0.0000 \\
\hline
\end{tabular}

Note: $* * *$ signals parameter significance at $1 \%$. 
Table 5 (b): Dependent variable $\triangle G B S$ - period 2007-17

(authors' own calculations in Eviews 10)

\begin{tabular}{|l|c|c|c|c|}
\hline & Coefficient & Std. Error & t-Statistic & Prob. \\
\hline$\beta_{20}$ & 0.001240 & 0.002030 & 0.610672 & 0.5415 \\
\hline$\beta_{21}$ & -0.001952 & 0.007876 & -0.247877 & 0.8043 \\
\hline$\beta_{22}$ & -0.002421 & 0.008794 & -0.275274 & 0.7831 \\
\hline$\beta_{23}$ & -0.002425 & 0.009893 & -0.245069 & 0.8064 \\
\hline$\beta_{24}$ & -0.012314 & 0.010156 & -1.212541 & 0.2255 \\
\hline$\beta_{25}$ & 0.010999 & 0.010328 & 1.064910 & 0.2871 \\
\hline$\beta_{26}$ & 0.006799 & 0.009091 & 0.747862 & 0.4546 \\
\hline$\beta_{27}$ & 0.006193 & 0.008324 & 0.743978 & 0.4570 \\
\hline$\beta_{28}$ & 0.008612 & 0.007212 & 1.194139 & 0.2326 \\
\hline$\alpha_{21}$ & $0.289723 * * *$ & 0.053088 & 5.457450 & 0.0000 \\
\hline$\alpha_{22}$ & 0.003718 & 0.058818 & 0.063214 & 0.9496 \\
\hline$\alpha_{23}$ & -0.013515 & 0.047503 & -0.284499 & 0.7761 \\
\hline$\alpha_{24}$ & 0.025974 & 0.047750 & 0.543950 & 0.5865 \\
\hline$\alpha_{25}$ & 0.022107 & 0.055280 & 0.399913 & 0.6893 \\
\hline$\alpha_{26}$ & -0.063958 & 0.054665 & -1.169996 & 0.2421 \\
\hline$\alpha_{27}$ & -0.070450 & 0.043368 & -1.624477 & 0.1044 \\
\hline$\alpha_{28}$ & -0.009933 & 0.052577 & -0.188927 & 0.8502 \\
\hline$\lambda_{2}$ & -0.006385 & 0.006414 & -0.995474 & 0.3196 \\
\hline
\end{tabular}

Note: $* * *$ signals parameter significance at $1 \%$.

Table 5 (a) and Table 5 (b) show that only $\lambda_{1}$ is statistically significant and negative while $\lambda_{2}$ is also negative but not statistically significant. This result implicitly means that the bond market (lead) embodied more rapidly the credit risk information than the $C D S$ market (lag) during the crisis period. The $C D S$ market, therefore, favored the process of adjustment towards the long-run equilibrium relationship.

\subsection{Italy}

We evaluate, for Italy, the existence of cointegration between the two series through the Augmented Dickey-Fuller Test detailed below in the Table 6 . 
Table 6: Augmented Dickey-Fuller Test - period 2007-17 (authors' own calculations in Eviews 10)

\begin{tabular}{|c|c|c|}
\hline \multicolumn{3}{|c|}{ Augmented Dickey-Fuller Test } \\
\hline \multicolumn{3}{|c|}{ Residuals } \\
\hline Country & t-Statistic & Prob. $^{*}$ \\
\hline Italy & -4.312386 & 0.0004 \\
\hline
\end{tabular}

The test suggests that the two series are cointegrated. The VECM estimation outputs are reported in the following Table 6 (a) and Table 6 (b).

Table 6 (a): Dependent variable $\triangle C D S$ - period 2007-17 (authors' own calculations in Eviews 10)

\begin{tabular}{|c|c|c|c|c|}
\hline & Coefficient & Std. Error & t-Statistic & Prob. \\
\hline$\beta_{10}$ & 0.000642 & 0.001543 & 0.415884 & 0.6775 \\
\hline$\beta_{11}$ & -0.070609 & 0.056135 & -1.257850 & 0.2086 \\
\hline$\beta_{12}$ & -0.020309 & 0.047841 & -0.424512 & 0.6712 \\
\hline$\beta_{13}$ & $-0.099282^{* *}$ & 0.043694 & -2.272200 & 0.0232 \\
\hline$\beta_{14}$ & $-0.077816^{*}$ & 0.040932 & -1.901086 & 0.0574 \\
\hline$\alpha_{11}$ & $0.165657^{* * *}$ & 0.051927 & 3.190204 & 0.0014 \\
\hline$\alpha_{12}$ & -0.027336 & 0.047535 & -0.575070 & 0.5653 \\
\hline$\alpha_{13}$ & -0.006220 & 0.043585 & -0.142717 & 0.8865 \\
\hline$\alpha_{14}$ & 0.044907 & 0.037114 & 1.209952 & 0.2264 \\
\hline$\lambda_{1}$ & $-0.008850^{*}$ & 0.004759 & -1.859872 & 0.0630 \\
\hline
\end{tabular}

Note: $* * *$ signals parameter significance at $1 \%$. 
Table 6 (b): Dependent variable $\triangle G B S$ - period 2007-17

(authors' own calculations in Eviews 10)

\begin{tabular}{|c|c|c|c|c|}
\hline & Coefficient & Std. Error & t-Statistic & Prob. \\
\hline$\beta_{20}$ & 0.000549 & 0.001636 & 0.335556 & 0.7372 \\
\hline$\beta_{21}$ & $0.104942^{* * *}$ & 0.040713 & 2.577601 & 0.0100 \\
\hline$\beta_{22}$ & 0.031092 & 0.039356 & 0.790035 & 0.4296 \\
\hline$\beta_{23}$ & -0.017617 & 0.050129 & -0.351437 & 0.7253 \\
\hline$\beta_{24}$ & -0.018998 & 0.039064 & -0.486334 & 0.6268 \\
\hline$\alpha_{21}$ & -0.008451 & 0.051488 & -0.164131 & 0.8696 \\
\hline$\alpha_{22}$ & $-0.124824 * * *$ & 0.048738 & -2.561113 & 0.0105 \\
\hline$\alpha_{23}$ & -0.042700 & 0.056113 & -0.760968 & 0.4467 \\
\hline$\alpha_{24}$ & -0.003914 & 0.042317 & -0.092501 & 0.9263 \\
\hline$\lambda_{2}$ & 0.007104 & 0.005353 & 1.327096 & 0.1846 \\
\hline
\end{tabular}

Note: $* * *$ signals parameter significance at $1 \%$.

Table 6 (a) and Table 6 (b) show that only $\lambda_{1}$ is statistically significant and negative while $\lambda_{2}$ is positive but not statistically significant. This result implicitly means that the bond market (lead) embodied more rapidly the credit risk information than the $C D S$ market (lag) during the sovereign debt crisis period. The CDS market, therefore, favored the process of adjustment towards the long-run equilibrium relationship.

\subsection{Spain}

As well as for all other peripheral countries, during the period 2007-17, there is cointegration between the series as supported by the Augmented Dickey-Fuller Test reported below in the Table 7 .

Table 7: Augmented Dickey-Fuller Test - period 2007-17 (authors' own calculations in Eviews 10)

\begin{tabular}{|c|c|c|}
\hline \multicolumn{3}{|c|}{ Augmented Dickey-Fuller Test } \\
\hline \multicolumn{3}{|c|}{ Residuals } \\
\hline Country & t-Statistic & Prob. $^{*}$ \\
\hline Spain & -4.440875 & 0.0003 \\
\hline
\end{tabular}


The test suggests that the two series are cointegrated. The VECM estimation outputs are reported in the following Table 8 (a) and Table 8 (b).

Table 8 (a): Dependent variable $\triangle C D S$ - period 2007-17 (authors' own calculations in Eviews 10)

\begin{tabular}{|c|c|c|c|c|}
\hline & Coefficient & Std. Error & t-Statistic & Prob. \\
\hline$\beta_{10}$ & 0.000405 & 0.001221 & 0.331873 & 0.7400 \\
\hline$\beta_{11}$ & $0.103261^{* *}$ & 0.042878 & 2.408238 & 0.0161 \\
\hline$\beta_{12}$ & $-0.094815^{* *}$ & 0.040659 & -2.331966 & 0.0198 \\
\hline$\beta_{13}$ & $-0.113123^{* * *}$ & 0.041434 & -2.730216 & 0.0064 \\
\hline$\beta_{14}$ & $-0.074822^{* *}$ & 0.037623 & -1.988731 & 0.0468 \\
\hline$\beta_{15}$ & 0.007671 & 0.038165 & 0.200985 & 0.8407 \\
\hline$\alpha_{11}$ & $0.106781^{* * *}$ & 0.029723 & 3.592508 & 0.0003 \\
\hline$\alpha_{12}$ & 0.047389 & 0.029994 & 1.579936 & 0.1142 \\
\hline$\alpha_{13}$ & 0.006228 & 0.028557 & 0.218078 & 0.8274 \\
\hline$\alpha_{14}$ & 0.032869 & 0.029085 & 1.130073 & 0.2586 \\
\hline$\alpha_{15}$ & 0.013339 & 0.029892 & 0.446237 & 0.6555 \\
\hline$\lambda_{1}$ & -0.005774 & 0.006369 & -0.906529 & 0.3647 \\
\hline
\end{tabular}

Note: $* * *$ signals parameter significance at $1 \%$. 
Table 8 (b): Dependent variable $\triangle G B S$ - period 2007-17

(authors' own calculations in Eviews 10)

\begin{tabular}{|c|c|c|c|l|}
\hline & Coefficient & Std. Error & t-Statistic & Prob. \\
\hline$\beta_{20}$ & 0.000505 & 0.001688 & 0.299370 & 0.7647 \\
\hline$\beta_{21}$ & 0.087649 & 0.055157 & 1.589089 & 0.1122 \\
\hline$\beta_{22}$ & -0.013662 & 0.045373 & -0.301104 & 0.7634 \\
\hline$\beta_{23}$ & -0.060831 & 0.057786 & -1.052688 & 0.2926 \\
\hline$\beta_{24}$ & -0.015360 & 0.050850 & -0.302058 & 0.7626 \\
\hline$\beta_{25}$ & 0.017913 & 0.047885 & 0.374086 & 0.7084 \\
\hline$\alpha_{21}$ & 0.054180 & 0.045182 & 1.199143 & 0.2306 \\
\hline$\alpha_{22}$ & -0.053048 & 0.038789 & -1.367596 & 0.1716 \\
\hline$\alpha_{23}$ & $-0.080777 * *$ & 0.041933 & -1.926346 & 0.0542 \\
\hline$\alpha_{24}$ & -0.044076 & 0.039393 & -1.118891 & 0.2633 \\
\hline$\alpha_{25}$ & -0.023836 & 0.044000 & -0.541711 & 0.5881 \\
\hline$\lambda_{2}$ & $0.021422^{* * *}$ & 0.007999 & 2.678084 & 0.0075 \\
\hline
\end{tabular}

Note: $* * *$ signals parameter significance at $1 \%$.

Table 8 (a) and Table 8 (b) show that $\lambda_{1}$ is not statistically significant and negative while $\lambda_{2}$ is positive and statistically significant. This result implicitly means that the $C D S$ market (lead) embodied more rapidly the credit risk information than the bond market (lag) during the sovereign debt crisis period. The latter market, therefore, favored the process of adjustment in order to restore the long-run equilibrium relationship.

\section{Economic Discussion}

A Palladini et al. (2011) stated that: «due to its liquid nature, the Euro Area CDS market seems to move ahead of the corresponding bond market in price adjustment, both before and during the crisis». Moreover, authors added: «There is an alternative causal interpretation of our results. The CDS market may lead in price discovery because changes in CDS prices affect the fundamentals driving the prices of the underlying bonds». It should be noted that the sample period analyzed by them run from 30th January 2004 through 11 th March 2011.

Without invalidating the results reported by the above-mentioned authors, we found that, at least with respect to the PIIGS countries - except Greece, the CDS market seems to move behind the corresponding bond market in the credit risk 
price discovery process during the entire period. Specifically, starting from the first quarter of 2007 up to the beginning of the fourth quarter of 2017. The only exception is represented by Spain.

In order to explain why we obtained this final result, it could be interesting have to deepen the peculiarities and the economic structure of each examined country.

The economic crisis emerged as a result of the problems occurred in the real estate sector in the United States, in 2007, it began to impact the economies of other countries in a short time (Krugman, 2009), with a heavy impact on the Euro Area countries. The public deficits and debt levels extremely increased, got worse the sustainability of public finance of the most fragile economies. Between them, Portugal, Ireland, Italy, Greece and Spain (PIIGS) were the most severely hit by the effects of the global economic crisis inside the European Union.

Reinhart et al. (2010) claimed that countries with high public debt exhibited stunted economic growth. "Austerity" was widely supported and considered as the real cure in order to restore the pre-crisis trend of economic growth.

The largest public debt among the analyzed country, during the sovereign debt crisis period, is definitely attributed to Italy, followed by Spain on the second place. On the third place comes Portugal, while on the fourth place comes Ireland. However, a more relevant information is given by the amount of public debt as percentage of GDP. With regard to this latter indicator, the worst position was occupied by Italy and the most favorable by Spain (see Table 9).

Table 9: Debt as a percentage of GDP - period 2007-17 (Bloomberg)

\begin{tabular}{|c|c|c|c|c|}
\hline $\begin{array}{c}\text { EA Peripheral } \\
\text { Countries }\end{array}$ & $\mathbf{2 0 0 7}$ & $\mathbf{2 0 1 0}$ & $\mathbf{2 0 1 4}$ & $\mathbf{2 0 1 7}$ \\
\hline Portugal & $63.60 \%$ & $93.50 \%$ & $123.60 \%$ & $127.70 \%$ \\
\hline Ireland & $24.90 \%$ & $94.90 \%$ & $107.60 \%$ & $69.50 \%$ \\
\hline Italy & $104 \%$ & $119.10 \%$ & $132 \%$ & $131.20 \%$ \\
\hline Spain & $36.20 \%$ & $60.10 \%$ & $97.70 \%$ & $96.70 \%$ \\
\hline Mean & $\mathbf{5 7 . 1 8 \%}$ & $\mathbf{9 1 . 9 0 \%}$ & $\mathbf{1 1 5 . 2 3 \%}$ & $\mathbf{1 0 6 . 2 8 \%}$ \\
\hline
\end{tabular}

It is possible to observe in Table 9 that, up to 2007, sovereign debt level (compared to GDP) was elevated for Italy (and Greece, not reported here) and the trend for Portugal began to move in a worrisome trend, while the relative position of Ireland and Spain looked relatively healthy. The low GBS and CDS spreads on sovereign debt indicated that markets did not expect a real default risk as well as a fiscal crisis such that it could threaten the stability of the whole Euro Area. However, all of the enumerated countries surpassed, in 2010, the criterion written in Maastricht Treaty, regarding the maximum amount for the public debt being $60 \%$ of GDP. 
In order to go deeper in these results it is useful to have a general look on the historical evolution of each (different) socio-economic context.

\subsection{Portugal}

The entrance of Portugal into the European Monetary Union led to historically low interest rates, with real rates approaching zero percent. Favorable credit conditions and expansionary fiscal policy were a powerful catalyst in both domestic consumption and investment that initially led to strong economic growth and low unemployment. In the early 2000s, however, Portugal continued not only to stress a current account deficit but started also to experience a steady increase in the unemployment rate. Unlike Greece, Ireland or Spain, where economic growth had been sustainably high before the crisis, Portugal experienced low growth since 2001 . Private domestic demand and wage costs' growth slowed down considerably during the next year once the economy had already reached its cycle of boom peak. In 2003, indeed, Portugal went into recession ( -0.9 percent), the only Euro Area country together with Germany (-0.2 percent) to register negative growth that year (Lourtie, 2011). In order to improve the low labor productivity (probably the real Achilles heel), the Government partially changed the labor legislation in 2004 and, more substantially, in 2007. Briefly, the Portuguese economy was in evident trouble long before being hit by the financial crisis, with persistent large twin deficits. The financial crisis undoubtedly contributed to undermine the fragile foundation of the economic structure. Between 2008 and 2009, the Portuguese Government decided the bailout of two Portuguese banks, specifically Banco Português de Negócios $(B P N)$ and Banco Privado Português (BPP) in order to avoid of exacerbating a potentially serious financial crisis in the real economy.

The Greek crisis in 2010 had negatively strong spillover effects on the reliability of the weakest European economies, especially Portugal. At the beginning of February, Greek 10 year bond rates spiked to more than 7 percent. The panic on the Eurozone sovereign bond market triggered by the Greek crisis affected Portuguese bonds more than the rest of the peripheral countries mainly because estimates for 2009 indicated a much higher than foreseen deficit of 9.3 percent of GDP (Lourtie, 2011). Financial investors were deeply worried about the excessive levels of debt in some EU countries and this anxiety resulted in the CDS premia and in the widening of government bond spreads. For 2010, the Portugal's budget deficit equaled $7.3 \%$ of its national gross product. Although exports, differently from the first half of the 2000s, grew in the 2006/2010 period on average above EU 15 average, the current account deficit remains high (off-set by higher energy prices, in particular oil). At the end of the same year, the opinion that Portugal, similarly to Greece and Ireland, can apply for international financial aid was often expressed (Górniewicz, 2011).

On April 2011, Portugal became the third Euro Area country to request international financial assistance from Troika. The latter approved a $€ 78$ billion bailout package in May 2011 on condition that Portugal agreed to adopt austerity measures and 
structural reforms. The country registered a progressive reduction of the budget deficit during these austerity years. On May 2014, Portugal officially became the second country to exit from the Troika bailout program.

Reuters source reports that, in 2017, the official full-year deficit target has been 1.4 percent (while the European Union demands deficits at or below 3 percent) and the debt-to-GDP ratio around 126 percent from last year's around 130 percent (the EU wants it at or heading down towards 60 percent). It should be recognised that these positive results in recent years were partly due to policies adopted by the Costa-led socialist Government ${ }^{10}$.

\section{$5.2 \quad$ Ireland}

Before the crash, Ireland had a gross debt-GDP ratio in 2007 of $25 \%$ and was famed "Celtic Tiger" due to its solid economic pace of growth. During the 1990s, indeed, the Irish Government had implemented a wide range of policies that helped to foster improvements in productivity, strengthening all measures in place starting from the 1960s. Employment rose steadily from 1.1 million in the late 1980 s to 2.1 million in 2007. Combined with steady improvements in productivity, the economy delivered a period of extraordinary growth: from 1987 to 2007, economic growth averaged 6.3\% per year (Whelan, 2014). This stable growth that generated budget surpluses allowed Irish politicians to lower tax rates and raised the annual public spending. Virtually, Ireland did not suffer from any budget deficit and the public debt was amounting only to $25 \%$ of the national gross product (Górniewicz, 2011). In 2007, with the bursting of the housing bubble (2001-2007) and the consequential banking crisis, Ireland's gears of the economy got stuck. As observed by Whelan (2014): «With population growing and incomes expanding rapidly, there were strong fundamental factors underlying housing demand. In addition, EMU allowed Irish financial institutions to provide access to mortgage finance at historically low rates. Mortgage rates, which had traditionally been over 10\%, collapsed to below 5\%. As a result, house prices in Ireland quadrupled in price between 1996 and 2007, a pace of increase double that seen in the United States over a similar period. The response to this increase in housing demand was an extraordinary construction boom».

Towards the end of 2007, Irish house prices began rapidly to fall. The following year, Ireland's economy entered into a severe recession. In particular, the crisis of the construction sector heavily expanded inside the whole economy, hitting also the strictly linked banking sector. The Irish Government had to intervene in order to save the banking sector from bankruptcy: it devoted the equivalent of $4 \%$ of the national gross product for capital injections into the financial institutions (Górniewicz, 2011). Moreover, the huge unemployment level ${ }^{11}$, in 2009, worsened

10 Antonio Costa became Portugal's first minister from 26th November 2015.

11 The unemployment rate surged to $12.5 \%$ on December 2009. 
the fiscal expenditure due to a relevant loss in income tax revenues and a strong increase in social welfare payments.

As noted by Górniewicz (2011): «Combined with the collapse of the industrial production, constantly increasing unemployment rate and the decrease in the private sector spending, the budget cuts contributed to the downturn of Irish national gross product by 3\% in 2008 and by about 7\% in 2009. Therefore, from the beginning of the economic crisis, the economy of the former Celtic tiger suffered a decrease of almost $10 \% »$.

Although the Irish Government carried out a plan of spending cuts in order to somewhat alleviate the public debt burden, during the second half of 2010, the Irish sovereign credit rating was decreased from AA to AA- by Standard \& Poor's due to the constantly increasing expenses dedicated to rescue the domestic bank sector (doom loop). Bank debts became state debt, which passed from $25 \%$ to $108 \%$ of GDP in four years (from 2007 to 2010). All this was promptly reflected in the valuation of country related credit default swaps - securities or bonds in case of a country's insolvency. The profitability of 10-year treasury bonds of Ireland reached, by 8 th September 2010, the so-far highest level of $5.9 \%$.

Towards the end of 2010, Ireland entered in the Troika bailout program: Irish Government received 67.5 billion of euros of loans for its rescue, while it has transferred a total sum of 89.5 billion of euros to its financial sector over the same time. 55.7 of these billions ended up in the pockets of creditor banks, mainly foreign banks (Vago, 2014).

On December 2013, Ireland became the first country to exit from the Troika bailout program.

What should be pointed-out is that Ireland represents a special case. Ireland had a huge development because it became a strategic venue for the American multinationals due to a favorable tax regime to foreign investments, its proximity to the most important markets and for linguistic reasons ${ }^{12}$.

Although Ireland is currently growing with a good pace, it continues not to register the pre-crisis levels.

\subsection{Italy}

The years of the so-called Italian "economic miracle" have laid the foundations for the creation of a solid industrial structure. In the 1960s, indeed, the level of employment was close to full employment and it was compatible with the balance of current accounts. In that decade, in fact, the balance of payments was constantly in surplus. How- ever, the first blow to Italian external competitiveness came from the increase in the unit labor cost (the famous $U L C$ ) following the substantial

12 Ireland, indeed, registers a relevant difference between GDP and GNP. The former is much higher than the latter due to the income generated and moved by these foreign multinationals. 
increases in nominal wages, well beyond the growth of the productivity, achieved by workers in the hot autumn (1969). The oil shock, in the early 1970s, gave the next blow (Cesaratto, 2016). From that moment on, a rising structural trend in the level of inflation began to define itself. Therefore, the weapon used by Italian Government for improving exportations was the targeted devaluation of the lira. This powerful and double-edged tool could not be used anymore when the country entered in the third and last phase of EMU (Economic and Monetary Union) in 1999.

Deflationary policies at European level as well as the loss of the weapon of devaluation have undoubtedly slowed Italian growth and consequently increased the difficulty of achieving increasingly stringent targets of public finance. The issue had huge implications for the weakened and reduced Italian industrial capacity. The Italian real GDP begun to fall already from the early 2000s and reached its peak in 2009.

In 2008, when the global crisis expanded also at European level, the Berlusconiled coalition offered an election manifesto inspired by principles of austerity and financial stability, which was unusual for a coalition that had previously supported expansion and very expensive infrastructural projects (Di Quirico, 2010). However, the Italian Government witnessed the most difficult situation during the summer of the 2011, when exploded the so-called "spread crisis" (the term "spread" refers to the differential between the 10-year BTP yield and that of the 10-year Bund). In May of the same year, S\&P revised the outlook on Italy from "stable" to "negative". When the 1st July was diffused the S\&P's bulletin that evaluated the public deficit (and debt) reduction plan drawn by Berlusconi-led Govt (May 2008 - November 2011), the negative advice had an immediate dramatic effect on the BTP-Bund spread that expanded radically. On 7th July, the BTP-Bund spread soared beyond the quota 226 basis points, the record from the birth of the Euro. After that day, new records were observed. The BTP-Bund spread stabilized in August, but in September, when the downgrade of Italy was announced by the $S \& P$ rating agency, both CDS spread and bond spread went through the roof. The entire Europe (especially France and Germany) focused on the Italian Govt measures on debt and growth. On 9th November, Berlusconi's Govt fell down and the President of the Italian Republic (Napolitano), on 16th November, instructed Mario Monti to constitute a new technical Govt. Europe reacted positively to that guards change. Indeed, the spread went down at 368 basis points on 6th December. However, it went up again at 500 basis points in the end of the year. Italy as well as Spain were very close to the default. The VLTRO (Very Long Term Refinancing Operation), launched at the end of 2011 by the ECB, avoided it happened.

In the same direction of all the other European peripheral countries, Italy adopted a series of structural reforms with the setting-up of the Monti-led Government about pensions, work and taxes. The Renzi-led Government tried to increase the Italian competitiveness continuing to follow the path traced by the previous technical govt and easing the labor market. Moreover, during these last years, the Government have had to face an additional issue related to huge public expenditure bore in order 
to save some financial institutions and support the enhancement entire banking sector.

In the years of the Euro, broadly speaking, Italy has recorded increasing and persistent imbalances of current ac- count balances. In particular, the Target 2 deficit is sensibly augmented in favor of Germany, the first economy and leading exporter of the Eurozone. Still nowadays, the country has trouble finding a competitive and stable growth pace. Political uncertainty, by the way, contributes to provide a less clear picture on the future growth expectations and economic relations with the other European countries.

\subsection{Spain}

The latest Spanish recession was undoubtedly much more serious in terms of decline in GDP and unemployment growth than the crisis of the mid-1970s and that of the early 1990s.

The economy grew quite strongly during the first years of the Euro and it has long been mainly based on the real estate sector. Between 2000 and 2008 the Spanish unit labor costs increased more than $30 \%$. In Eurozone only the Greek and the Irish unit labor costs increased stronger (Gruppe et al., 2014). According to Loman et al. (2015):

«In the pre-crisis years, cheap access to foreign capital due to euro accession fuelled a huge housing bubble in Spain. Foreign capital was not allocated to high yielding investment, but used to finance construction activity. Banks, in particular regional savings banks, lent enthusiastically. Meanwhile, the savings rate fell and Spain's competiveness eroded due to rapid wage increases (and wage moderation in Germany). As a result, the current account deficit increased to a dramatic 9.8\% of GDP in 2007. Spain entered the crisis with a budget surplus (2\% of GDP in 2007) and modest public debt (36\% of GDP). However, the huge current account deficit, bad lending by its banks and an oversupply of housing left Spain very vulnerable when the Great Recession started ». During the pre-crisis years, the Spanish foreign debt consisted mainly of private debts, debts incurred by the Spanish banking system with foreign banks to finance the real estate boom. After the bursting of the housing bubble, the Spanish Government took over part of the bank debts. This latter did it by issuing securities largely purchased from foreigners. The "private" foreign debt has therefore turned into a "public" foreign debt. The Spanish foreign debt has essentially remained the same, but has changed its shape when the state has taken on private foreign debts (Cesaratto, 2016). GDP began to fall in Spain in the third quarter of 2008 and continued to diminish throughout 2009, making for six consecutive quarters of declines (Ortega et al., 2012). Moreover, the loss of foreign direct investments was an additional negative boost for the domestic economy. In 2009 , indeed, ninety per cent of the bonds issued were characterized by a maturity shorter than a year (Górniewicz, 2011), symptomatic of a weaker credibility of the country. The local Government adopted, in order to avoid a worsening of Spain's 
credit rating (and, thus, a higher cost of debt), austerity measures to control the budget deficit and debt stock. Nevertheless, these measures (thought to increase competitiveness and redress trade balances) contributed to an additional downward pressure on economic growth, exacerbating the flatted domestic demand. In 2010, the level of unemployment reached nearly $20.5 \%$.

The crisis has manifested itself in all its gravity in 2011, when the Government had the necessity of rolling long-term bonds (Bonos). On that occasion, Spain as well as Italy were very close to the default. As I already stated, the VLTRO has been vital for the rollover of the public debt by national banks for both Spain and Italy (since foreign investors decided to reduce their exposure, respectively, on Bonos and BTPs). In 2012, the Rajoy-led Government (2011-16) asked to EU for a loan of 100 billion euros to restructure the national banking sector within the framework of the structural reform strategy (which also included the labour market reform). Structural reforms have favoured the growth recovery and laid the foundation of a sounder economy. Notwithstanding the recent political instability due to the Catalonia referendum (2017), economic growth remains robust reaching over 3\% in 2017 for the third consecutive year.

\section{Conclusions}

In this paper, we analyzed the lead-lag relationship between the PIIGS - except Greece 10-year CDS premia and the respective government bond spreads (GBS) series by employing daily data, from January 2007 to October 2017, provided by Bloomberg. The analysis of these dynamic intermarket connections allow market operators to capture signals of inversion or trend reinforcement and then to implement worthwhile strategies. Moreover, for policy-makers, an in-depth knowledge of these dynamics creates the conditions for adopting timely and wellbalanced monetary policies. This paper proposes to provide an additional contribution to the existing literature focusing on the potential impact on the price discovery process of the sovereign credit risk and on eventual differences among Eurozone peripheral countries during this last decade of monetary policy easing. Specifically, we would like to highlight how traditional markets can change in particular economic contexts and be deeply affected by monetary policies. Results prove that during the entire decade started with the Lehman Brothers collapse, the CDS market leads the bond market incorporating more rapidly the sovereign credit risk information only in Spain. The opposite dynamic shows for Portugal, Italy and Ireland. The CDS market, therefore, continues to work properly only in Spain. 


\section{References}

[1] Amadei, L., Di Rocco, S., Gentile, M., Grasso, R. and Siciliano, G. (2011). Credit Default Swaps: Contract Characteristics and Interrelations with the Bond Market. SSRN Electronic Journal. https://papers.ssrn.com/sol3/papers.cfm?abstract_id=1905416

[2] Anelli, M., Patanè, M., Toscano, M., and Gioia, A. (2021). The Evolution of the Lead-lag Markets in the Price Discovery Process of the Sovereign Credit Risk: the Case of Italy. Journal Of Applied Finance \& Banking, 151-175. doi: 10.47260/jafb/1127

[3] Andenmatten, S., \& Brill, F. (2011). Did the CDS market push up risk premia for sovereign credit?. Swiss Journal Of Economics And Statistics, 147(3), 275302. doi: $10.1007 / \mathrm{bf} 03399347$

[4] Cesaratto, S. (2016). Sei lezioni di economia. Reggio Emilia: Imprimatur.

[5] De Jong, F. (2002). Measures of contributions to price discovery: a comparison. Journal Of Financial Markets, 5(3), 323-327. doi: 10.1016/s13864181(02)00028-9

[6] Di Quirico, R. (2010). Italy and the Global Economic Crisis. [ebook] Bulletin of Italian Politics. Available at: https://www.gla.ac.uk/media/media_191024_en.pdf

[7] Duffie, Darrell (1999). Credit Swap Valuation. Financial Analysts Journal, 55(1), pp.73-87. Available at:

https://www.darrellduffie.com/uploads/pubs/DuffieCreditSwapValuation199 9.pdf

[8] Elton, E., Gruber, M., Agrawal, D., \& Mann, C. (2001). Explaining the Rate Spread on Corporate Bonds. The Journal Of Finance, 56(1), 247-277. doi: 10.1111/0022-1082.00324

[9] Engle, R., \& Granger, C. (1987). Co-Integration and Error Correction: Representation, Estimation, and Testing. Econometrica, 55(2), 251. doi: $10.2307 / 1913236$

[10] Fontana, A., \& Scheicher, M. (2016). An analysis of euro area sovereign CDS and their relation with government bonds. Journal Of Banking \& Finance, 62, 126-140. doi: 10.1016/j.jbankfin.2015.10.010

[11] Gonzalo, J., \& Granger, C. (1995). Estimation of Common Long-Memory Components in Cointegrated Systems. Journal Of Business \& Economic Statistics, 13(1), 27. doi: 10.2307/1392518

[12] Górniewicz G. (2011). Public finances crises within the countries of PIIGS group. Studia UBB Negotia, LVI, 2. https://www.ceeol.com/search/articledetail id $=275689$

[13] Gruppe, M., \& Lange, C. (2014). Spain and the European sovereign debt crisis. European Journal Of Political Economy, 34, S3-S8. doi: 10.1016/j.ejpoleco.2013.08.006

[14] Gyntelberg, J., Hördahl, P., Ters, K. and Urban, J. (2016). Arbitrage Costs and the Persistent Non-Zero CDS-Bond Basis: Evidence from Intraday Euro 
Area Sovereign Debt Markets. SSRN Electronic Journal. https://papers.ssrn.com/sol3/papers.cfm?abstract_id=2866893

[15] Ito, T. (2016). The behaviour of sovereign CDS and government bond in the Euro zone crisis. International Journal Of Monetary Economics And Finance, 9(2), 102. doi: 10.1504/ijmef.2016.076478

[16] Krugman, P. (2009). The return of depression economics and the crisis of 2008. New York: W.W. Norton.

[17] Liew, V. K., (2004). What lag selection criteria should we employ? Economics Bulletin, 33(3), pp. 1-9. doi: 10.12691/ajrd-5-3-4

[18] Loman, H. and Wijffelaars, M. (2015). Eurozone (debt) crisis: Country Profile Spain. [online] Rabobank Economic Research. https://economics.rabobank.com/publications/2015/december/eurozonedebt-crisis-country-profile-spain/

[19] Lourtie, P. (2011). Understanding Portugal in the Context of the Euro Crisis. Peterson Institute for International Economics and Bruegel. https://www.piie.com/publications/papers/lourtie20110913.pdf

[20] Ortega, E., \& Peñalosa, J. (2012). The Spanish Economic Crisis: Key Factors and Growth Challenges in the Euro Area. SSRN Electronic Journal. doi: $10.2139 /$ ssrn.2016027

[21] Palladini, G. and Portes, R. (2011). Sovereign CDS and Bond Pricing Dynamics in the Euro-Area. NBER Working Paper Series. http://www.nber.org/papers/w17586

[22] Reinhart, C. and Rogoff, K. (2010). Growth in a Time of Debt. American Economic Review, 100(2), pp.573-578. doi: 10.1257/aer.100.2.573

[23] Vago, C. (2014). Il "salvataggio" dell'Irlanda: 67,5 miliardi di euro di prestiti, 89,5 miliardi trasferiti alle banche - NCIMS. [online] NCIMS. https://www.nonconimieisoldi.org/cosa-non-va- nella-finanza/il-salvataggiodellirlanda-675-miliardi-di-euro-di-prestiti-895-miliardi-trasferiti-allebanche/

[24] Whelan, K. (2014). Ireland's Economic Crisis: The Good, the Bad and the Ugly. Journal Of Macroeconomics, 39, 424-440. doi: 10.1016/j.jmacro.2013.08.008

[25] Wooldridge, J. (2003). Introductory econometrics. Mason, Ohio: Thomson/South-Western. 


\section{Appendix}

Table 10: Lag Order Selection Criteria

\begin{tabular}{|l|c|c|}
\hline Country & Lag & Hannan-Quinn Information Criterion \\
\hline Portugal & 5 & $-2.643683^{*}$ \\
\hline Ireland & 8 & $-0.038195^{*}$ \\
\hline Italy & 4 & $-4.910123^{*}$ \\
\hline Spain & 5 & $-5.229086^{*}$ \\
\hline
\end{tabular}

*indicates lag order selected by the criterion

Source: authors' own calculations in Eviews 10

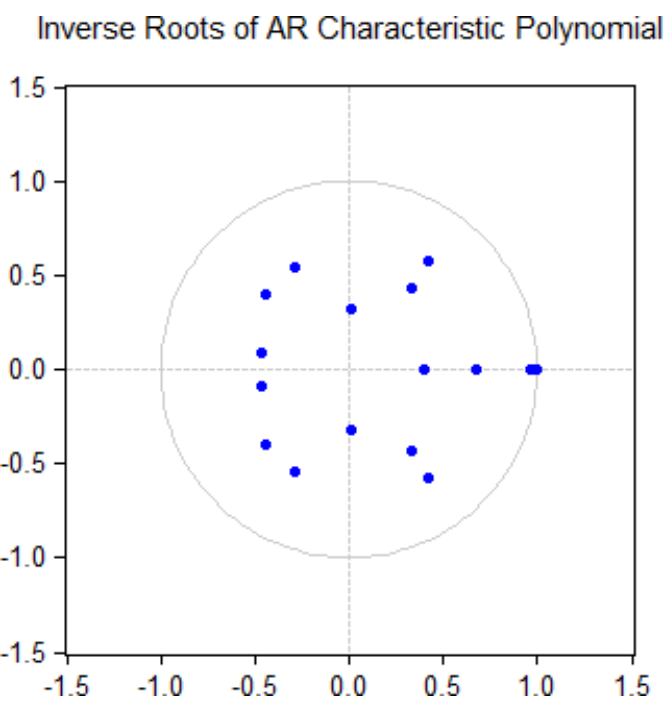

Figure 5: Inverse Roots of AR Characteristic Polynomial (Portugal). Source: authors' own calculations in Eviews 10 based on Bloomberg data. 


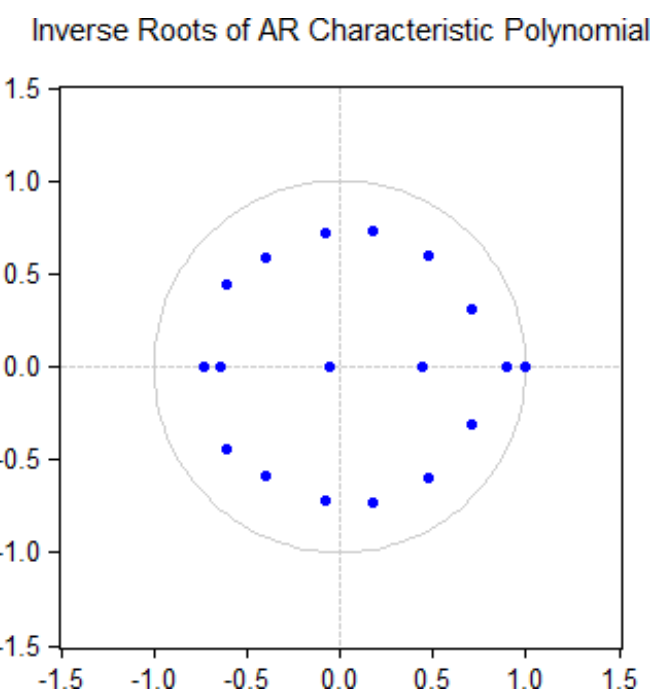

Figure 6: Inverse Roots of AR Characteristic Polynomial (Ireland). Source: authors' own calculations in Eviews 10 based on Bloomberg data.

Inverse Roots of AR Characteristic Polynomial

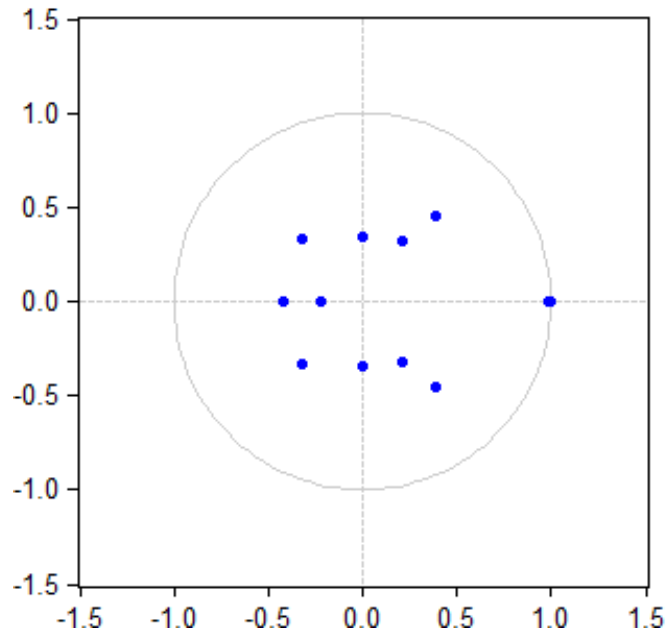

Figure 7: Inverse Roots of AR Characteristic Polynomial (Italy). Source: authors' own calculations in Eviews 10 based on Bloomberg data. 
Inverse Roots of AR Characteristic Polynomial

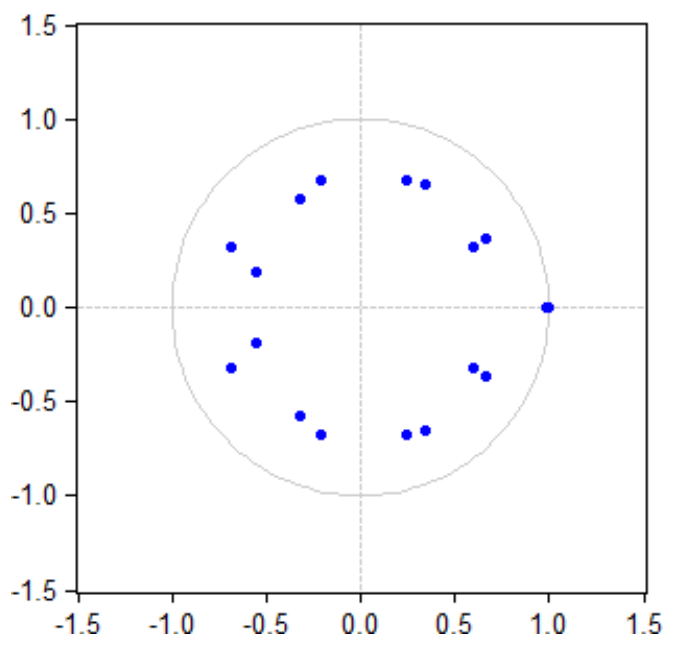

Figure 8: Inverse Roots of AR Characteristic Polynomial (Spain). Source: authors' own calculations in Eviews 10 based on Bloomberg data. 